\title{
Carboxypeptidase E
}

National Cancer Institute

\section{Source}

National Cancer Institute. Carboxypeptidase E. NCI Thesaurus. Code C95809.

Carboxypeptidase E (476 aa, $\sim 53 \mathrm{kDa}$ ) is encoded by the human CPE gene. This protein is involved in prohormone processing. 